\title{
The Railway Systems of West Africa
}

\section{Captain H. O. Mance D.S.O., R.E.}

To cite this article: Captain H. O. Mance D.S.O., R.E. (1913) The Railway Systems of West Africa, Royal United Services Institution. Journal, 57:420, 167-194, DOI: 10.1080/03071841309427152

To link to this article: http://dx.doi.org/10.1080/03071841309427152

\section{册 Published online: 11 Sep 2009.}

Submit your article to this journal $\pi$

Џll Article views: 9

Q View related articles $\longleftarrow$ 


\title{
THE RAILWAY SYSTEMS OF WEST AFRICA.
}

\author{
By Captan H. O. Mance, D.s.o., R.E.
}

On Wednesday, 22nd January, 1913, at 3 p.m.

Sir Clement L. Hill, k.c.B., k.C.s.g., M.P., in the Chair.

\section{Synopsis of Lecture.}

INTRoductory. Objects of Railway Construction in West Africa : Effective Occupation-Strategic-Development of External CommerceAdministration-Local. GeNeral Factors whil Govern Location of Rallways in West Africa : Ports-Early Profit on Working -Natural Resources-Competition-Physical Configuration-Political Frontiers-Cross-Country Lines. Existing and Proposed French Rallways : Existing French Railways-French Programme of Main Line Construction - Consideration of Thiès-Kayes Line-Liberia. German Rallways: Togoland-Cameroons. Sirrra Leone aNd the Gold CoAst: Sierra Leone -Gold Coast. Nigeria : Existing Railways-Extensions in Southern Nigeria-Eastern Trunk Line-Cross-Country Line in Northern Nigeria - Western Trunk Line-Possible Extension to Zindar. Statistics Illustrating the Results of Working of West African Railways. Future Connections Between International Systems : Suggested TransAfrican Railway-Standard Gauges of West Africa. Conclusion. APPENDIX I : Railway Extensions and Harbour Improvements Proposed for Execution under Loan of $£ 6,000,000$ raised by French West Africa. AppFNDIx II : Approximate Dates and Cost of Construction and Results of Working of West African Railways. Population Map: pp. I84 and 185. Gentral Map: Facing page 194.

THE CHAIRMAN : Ladies and gentlemen, before we proceed to any other business, I should like to read you a letter which has been received from Mr. Harcourt, who asked me to apologize for his absence to-day, and to explain the very great interest which he takes in this matter:

"Dear Sir Clement Hill, I see that you are to take the chair at Captain Mance's lecture on 'The Railway Systems of West Africa.' at three o'clock on Wednesday, 22nd. I should be glad if you would mention, when you do so, that I should certainly have attended the lecture myself, but for the fact that, on that day, I am obliged to be in Lancashire. As you know, I am especially interested in the railways of our Tropical Colonies, and have done not a little myself to encourage and prolong them.

Yours very sincerely,

L. Harcourt."

That, as you know, is perfectly true. 
I have also had a letter from Mr. Jonathan Holt, of John Holt and Company, as follows :-

"I much regret being unable to be present to hear the lecture from Captain H. O. Mance, upon Railways in West Africa. I am sure what he will have to say on this subject will be most interesting and instructive. During the time Captain Mance has been in Northern Nigeria, in addition to his own particular work, he has taken an extraordinary amount of interest in various matters appertaining to the trade, and to the development of the exports from that country. He has gone to endless trouble, no doubt at considerable inconvenience to himself, to give the merchants and traders much valuable information. I am only sorry that, if only to show my appreciation of Captain Mance and what he has done, I cannot be present on Wednesday afternoon.

$$
\begin{aligned}
& \text { I am, dear Sir, } \\
& \text { Yours faithfully, } \\
& \text { Jonathan Hotr." }
\end{aligned}
$$

I have now great pleasure in introducing to you Captain Mance, who will read the paper. Captain Mance is himself in the Royal Engineers, and has the Distinguished Service Order, and he is the son of a very well-known man, Sir Henry Mance, who was the inventor of the heliograph. Captain Mance has also been through the South African war as Staff Officer to the Assistant-Director of Railways, and was Deputy-Assistant Director of Railways and Armoured Trains on the Kimberley line. He was also employed in the construction of the BaraKano Railway from 1908 to $191 \mathrm{I}$, and so he is thoroughly qualified to read us a paper on that subject, and I am certain we may look forward to having a very interesting lecture, and, I hope, discussion to follow. I will now ask Captain Mance to read his paper.

THE LECTURER: Sir Clement Hill, ladies and gentlemen,

The present time is a critical one in the railway development of IVest Africa. European nations are realizing the immense importance of tropical possessions. Everyone has heard of rubber and minerals, especially gold and tin, and even of cotton as being articles obtained from West Africa, but what is equally important, though less generally known, is our dependence on the tropics for increasing supplies of the oil products ultilized for edible purposes, for soap, and for candles. The delimitation of international boundaries and pacification of the country have paved the way for systematic economic development, which can only be obtained by improved means of communication.

The French have taken the lead with a comprehensive scheme aiming at linking together their West African possessions, and one of the first problems of the amalgamated Nigerias will be the framing of a railway policy on which the economic future of this rich possession will largely depend. To the East 
again the Germans in the Cameroons, with the territory recently ceded by the French, are confronted with the necessity of a co-ordinated railway policy.

The moment is therefore opportune to review the siturtion generally, in the hope that the various factors will present themselves in their proper proportion. I propose to consider, firstly, the general objects of railway construction in West Africa; secondly, the principal factors which influence the choice of the lines of railway development; and then to survey what has already been done, and consider some of the problems which still remain to be solved. The opinions advanced in this lecture are personal views and bear no official authority. It is not claimed that they are original. Some of them were first advanced years ago.

I am indebted to a large number of sources for the information embodied in this paper, and more particularly to published official reports relating to British and French colonies, to l'Afrique Française, La Dépêche Coloniale, Les Chemins de Fer Coloniaux Français, by Godfernaux, and the Deutscher Kolonialatlas.

\section{ORJECTS OF RAILWAY CONSTRUCTION IN WEST AFRICA.}

EFFEctive Occupation.-One of the first objects of railway construction in West Africa, or for the matter of that in any of our more recently acquired tropical dependencies, is to attain effective occupation. The Uganda Railway was built primarily to stop the slave trade. The Soudan Railway was undertaken to aid in the reconquest of that country. The Senegal-Niger railway was planned to secure for France the basin of the Upper Niger. This method of occupation is far more effective than military conquest. It possesses, however, the disadvantage that the information available is not usually sufficient to enable the railway to be located for the best future welfare of the country. The consideration of effective occupation is therefore in itself a temporary one.

StRATEGIC.-After the pacification of a colony there may remain strategic reasons for the construction of railways, which would play an important part in the event of a Mahommedan rising emanating from one of the uncontrolled regions of North Central Africa. Any general scheme of railway development based on economic grounds will meet such requirements; and these will at most only influence the order in which the component projects are carried out.

As regards international hostilities, it is not likely that problematical strategic considerations will be allowed to influence a railway policy upon which success in international commercial rivalry may depend.

Developuent of External Commerce.-A little reflection will show that the development of external commerce should 
be the paramount object of railway construction, whether looked at from the point of view of affording the inhabitants a fruitful field for energies released from less productive occupations by the advent of "Pax Britannica" or its Continental equivalent; or from the point of view of European trading firms, and manufacturers of goods for native markets who are dependent on cheap transport for the extension of trade; or from the standpoint of the administration, and, above all, the Treasury, out of whose clutches it is the desire of every self-respecting colony to extricate itself by dispensing with a grant-in-aid. West Africa has enormous resources, of which, in many cases, a microscopic portion supplies the local requirements. The prosperity of these countries prior to European occupation varied with the extent of their trade with neighbouring countries, carried on, as it was, under dangers and difficulties. Further increase in prosperity can chiefly be obtained by widening the markets for the products of the country, and improving the efficiency of production, both of which objects are effected by extending the means of transport.

Aduinistration.-Administrative reasons, such as intercommunication between the different arteries serving outlying portions of a dependency, or the necessity for access to healthy stations, are permanent reasons, the relative importance of which, compared with economic development, will vary in different localities, and with the state of progress which has been reached.

Local.-Finally, it is possible that railways may be specially built for such local purposes as to transport labourers and food from populous areas to mining centres, to connect the more fruitful food-producing countries with areas liable to famine, and to distribute local coal in competition with imported supplies. Internal native trade is more likely to be modified by than to influence railway construction.

Thus we are led to approach the problem of railway location primarily with the object of fostering external commerce while giving due regard to administrative facilities.

\section{GENERAL FACTORS WHICH GOVERN LOCATION OF RAILWAYS IN WEST AFRICA.}

Ports.-The first practical consideration which at once presents itself is the question of ports. West Africa affords a striking example of what can be done in the way of trade on a surf-bound coast without ports, but it is easily seen that only the more lucrative forms of trade can survive the inconveniences and extra cost, both direct and indirect, involved by the primitive method of conveying cargo between the shore and ocean steamers by surf boats, which in bad weather may have to suspend operations. It will, therefore, pay to divert railways considerable distances from their shortest route to the coast to 
obtain the greater capacity, reliability, and cheapness afforded to trade by good, or better, ports.

Early Profit on Working.-No administration is likely to construct a railway without ensuring, as far as possible, that the immediate return will make the undertaking pay its way from the commencement. In IVest Africa, with its ubiquitous natural resources and possibilities, the limiting factor in the development which can be brought about by improved communications is the density of population, and it will therefore usually pay quickest to build railways in the more populous districts. The effects of long periods of slave raiding have, however, altered the distribution of population in a striking degree, so that at present, population density cannot be regarded as a reliable index to the natural resources of the various districts to the extent that would be expected in a more settled country; and in the absence of special influences, it will take several generations to bring these factors into close relation. It must also be borne in mind when studying population charts, that areas suitable for growing native foodstuffs of low commercial value may support a large population, independently of transport facilities, for the lack of which a district richer in sylvan and mineral wealth, but less suited for producing food staples, may remain comparatively uninhabited.

A portion of a population density chart of West Africa, compiled from the latest available data, has been reproduced on pages 184,185 . The data cannot be regarded as final, and the distribution shown will doubtless be considerably modified in the light of further knowledge of the country. Such as they are, however, these figures of population density are well worth study by those interested in West African problems. The depopulated area due to slave-raiding will be seen extending from east to west, between the Hausa States and the coast provinces of Nigeria, and still further to the west in the Northern Territories of the Gold Coast and the Ivory Coast. The scale on the chart shows the density, expressed in the number of inhabitants per square kilometre. This multiplied by two-and-a-half will give, approximately, the number per square mile. The densest areas shown are those with over Ioo per square mile, but there are some portions of Southern Nigeria which are far more thickly populated. In the district of Ikot Ekpene the population is estimated at 430 per square mile. It will be noted that Nigeria is by far the most densely populated part of West Africa.

Natural Resources.-Coupled, therefore, with the knowledge of the present distribution of population, it is most important to take stock of potential riches, sylvan, agricultural, and mineral, of the country it is proposed to develop. Perhaps it is for this purpose that our Continental neighbours in West 
Africa usually send a scientific mission to report on the districts it is contemplated developing by railways.

So far as we have got, our general scheme of railway development will consist of one or more railway systems starting from the best ports and disposed to drain, in the most effective manner, the areas endowed with the greatest resources, whether developed or potential, precedence being given to the more densely populated areas in view of the importance of each portion of the scheme paying its way as it is constructed.

Competition.-How far this latter consideration may be allowed to weigh, will depend a good deal on the point next to be considered, namely, the possibility of competition with existing or future railway systems or water transport. This is not so important in cases where the opposition railway is controlled by the same administration, but where, for example, the railways of two adjoining European Powers are likely to compete for the trade of an important district, everything may have to give way to obtain the cheapest outlet for through traffic. It is always possible to serve rich non-competitive areas, lying off the direct route, by branch lines.

The products of West Africa have, moreover, to compete in European markets with similar commodities from other origins, and the future prosperity of a colony may lie in commodities, the exploitation of which depends on the cheapness of transport. It may be advanced that a longer line through a richer country can profitably quote lower rates than a more direct line, which cannot reckon on a nucleus of lucrative intermediate traffic; but in the long run, under the stress of competition for a large volume of traffic, assuming equal facilities, rates as a whole will bear relation to the bed rock of working expenses, so that it may well pay to build an unproductive section as part of a general scheme for the best ultimate good of the country.

Physical Configuration.-The same considerations which justify a comparatively unremunerative section may make it worth while undertaking a route which is more costly to construct by reason of physical difficulties, in order to attain lower ultimate expenses. The additional expenditure may be devoted to obtaining a shorter line through more difficult country, or to reducing the ruling grade. It is hardly necessary to point out that the added charge on traffic due to interest on increased capital expenditure remains constant, and the extra cost per ton mile therefore becomes less as the traffic increases, so that at a certain stage of development this extra cost is more than covered by the reduction of working expenses. A happy mean in this respect has been attained in Northern Nigeria on the BaroKano Railway. Here expenditur'e was not stinted where necessary to obtain the best possible grade, but in other respects a cheap line was constructed capable of being improved as 
traffic increases. This type of line is destined to play an important part in the development of West Africa.

As a general rule, however, it is evident that physical configuration exercises an important influence on the situation of railways.

Political Frontiers. - The weightiest economic considerations may have to give place to the fortuitous disposition of international frontiers. The French had to abandon their original scheme for the line of penetration in French Guinea, as it was found that the most favourable route lay partly within the hinterland allotted to Great Britain. The existence of protective fiscal tariffs may artificially influence the lines of railway development. The case of Sierra Leone and French Guinea may be cited and will be referred to again.

Cross Country Lines.-As regards the lines constructed chiefly for administrative purposes, these will be in the nature of cross lines, and will act as feeders to the coast trunk lines. Unless likely to form part of a cross trunk line, deviations from the shortest route will only affect the local area served. It must be remembered when scheming a railway system, that the construction of a connecting link between two systems almost invariably introduces the factor of competition by alternative routes.

\section{EXISTING AND PROPOSED FRENCH RAILWAYS.}

EXISTING French RaILways.-I will now briefly review what has been done in the past. Precedence must be given to the French, who had the honour of starting to build the first railway in West Africa, 15 years ahead of any other nation, and who lead to-day with their West African railway policy.

The port of Dakar has wharves along which ocean steamers can berth. It is becoming an important coaling station for South American lines of steamers, and with the adjoining port of Rufisque, is the present outlet of the French Western Soudan.

The Dakar-St. Louis line, 165 miles long, commenced in 1882 , completed in 1885 , taps the whole of the water-borne trade of the Senegal River, which has no practicable outlet to the ocean by reason of its bad bar.

The Kayes-Bamako-Koulikoro Railway, 346 miles long, originally proposed by Faidherbe in 1863 , connects the head of navigation on the Senegal River with the head of the longest navigable reach on the Niger. It was commenced in 1881 , and, at the cost of many lives, and after many vicissitudes, was finally completed in 1904, securing to the French the basin of the Upper Niger.

It was decided as early as 1878 , when a commission was appointed in France to report on the railway development of 
French West Africa, that the two above railways should be eventually linked together, and the correctness of this policy has been borne out by the fact that the navigation of the Senegal River to Kayes, though admitting boats with 1,000 tons cargo for a short period of high water, is found to be too uncertain to be relied on as the outlet of the Upper Niger country. A railway is therefore being constructed to link together Thiès and Kayes, and thus cut out the Senegal. This line, which will be about 425 miles long, is being constructed from both ends, and has been completed all but about 180 miles.

A line from Konakri, a comparatively good port, with a wharf for ocean steamers, was started in 1900, and completed to Karoussa ( 367 miles) in rgro. It is now being extended a further 40 miles to Kankan, whose importance as a commercial centre may be deduced from the fact that 14 European firms were installed there while yet the railway was hundreds of miles away. Both the Niger from Karoussa (250 miles away) and the Milo from Kankan are navigable for small steamboats to Bamako during the high-river months, and by large canoes all the year round. Feeder roads have been constructed from the railway in the most likely directions for future branch lines.

On the Ivory Coast a line 195 miles long has been constructed from Abidjan through the forest belt to Bouake. Progress was delayed by the native rising early in 1910, when the line was attacked and damaged in places. There is a jetty through the surf at Grand Bassam, and the facilities, which appear to have been very unsatisfactory, have recently been improved. An attempt to form a seaport at Abidjan by joining the lagoon with the ocean failed and had to be abandoned. As a result the railway terminates on a lagoon, over 20 miles from Grand Bassam, its sea-port. One of the suggestions to get over the difficulty is to extend the railway from Abidjan across the lagoon to Port Bouet, and build one or two jetties at the latter place. Another scheme is to improve Grand Bassam and link it by rail with Abidjan via Bingerville.

In Dahomey a railway 162 miles long exists from Kotonu to Savé, with a branch 20 miles along the coast to Segboroué. A tramway of the same gauge runs from Porto Novo to Sakete, 25 miles long, and now being extended a further 25 miles. Owing to the lack of a harbour at Kotonu, where there is only an iron jetty projecting through the surf, a large proportion of the trade of Porto Novo is sent via the coastal lagoons to Lagos for shipment.

Frenchi Programine of Main Line Construction.-The Government appears to have organized the collection of information bearing on the extension of railways, and in May, I9I $\mathrm{x}$, the Governor-General of French West Africa proceeded on a tour embracing all the colonies under his jurisdiction. On his return a general scheme of railway and harbour development, estimated to cost over 19 millions sterling, in addition to the 
funds already voted, was promulgated, to commence which a loan of 150 million francs, or six millions sterling, is being raised. Of this amount $£ 240,000$ is allocated to improving the port of Dakar, $\mathcal{E}_{120,000}$ to the port of Konakri, and $\mathcal{E}_{40,000}$ for the survey of and preliminary work on a port on the Ivory Coast. The attached map shows generally the proposed scheme of railways, which is on the lines of one foreshadowed in 1906. Starting from Dakar a main artery will extend via Thiès, Kayes, Bamako, Buguni, Boromo, Wagadugu, Fada N'Gurma, Paraku to Kotonu, a distance of about 2,000 miles. From this main artery two lines will extend to the coast, one from Buguni via Kankan and Kurussa to Konakri, the other from Boromo via Boualé to Abidjan. Two branches will be built to the Niger. The first from Paraku to Gaya, the head of what may be termed the middle navigable section of the Niger, and the second from Wagadugu to Ansongo at the foot of the longest navigable section of the Niger. It may be mentioned that, in the event of the suggested Trans-African Railway being constructed, to link together Algeria with the Congo Railway system via Lake Chad, a branch would be made either from Selet or In Gessan to Ansongo to connect with the French West African system. Kankan will be connected with Dimbokro on the Ivory Coast Railway by a direct line through. Beyla and Daloa, and finally there will be a cross line between the Thiès-Kayes and the French Guinea Railway. The portions of this system, which it is intended to carry out by I918, out of the forthcoming loan, are shown in Appendix $\mathrm{I}$. The Governor-General, however, will be able to divert expenditure from one line to another, so that it may be possible, for example, for the line to be continued on from Paraku to the Niger, within the next few years. This scheme is only intended to provide for the trunk lines of the future railway system of French West Africa. Branch lines will be built to develop special districts as the need arises.

It will be noted that the existing centres of densest population are tapped as far as possible without deflecting the trunk lines from the shortest routes to the interior.

Consideration of Thiès-Kayes Line.-The Thiès-Kayes Railway was deflected to the southward to tap the rich basin of the Gambia instead of the almost desert hinterland, and to save as much as possible of the trade from being diverted to British channels. A proposal, made in 1907, to go direct from Tamba Counda to Talary, thus shortening the rail journey from the interior by 42 miles, was overruled on the grounds of costing f200,000 more. Possibly the more immediate advantage of the Kayes-Ambidédi section which has just been commenced, influenced the decision. I cannot help thinking that the future will prove that the more direct route would have been best, with a branch 25 miles long from Kayes to Ambidédi if necessary. A scheme has been suggested to build a branch line, 13 miles long, from Guinguineo to Kaolak on the Saloum River, which is 
navigable at all times, thereby saving some 90 miles as compared with Dakar. It must be remembered, however, that the Gambia River is already navigable for vessels of $13 \mathrm{ft}$. draft all the year round to McCarthy's Island, 153 miles from Bathurst, and the depth is now being improved to $15 \mathrm{ft}$. Nianimaru, some $3^{0}$ miles below McCarthy's Island, is stated to be accessible at all times by fully-loaded ocean vessels drawing about 20 feet. It is, therefore, not unreasonable to suppose that a short branch line to McCarthy's Island, or, better still, to the vicinity of Nianimaru, might make the Gambia the future commercial outlet of French Western Soudan. The saving in the rail journey to McCarthy's Island as compared with Dakar, would appear to be about 180 miles.

Comparing the Dakar, McCarthy's Island, and Konakri routes : from Bamako to Dakar via the Thiès-Kayes route will be 810 miles; from Bamako to Konakri via the Niger to Karoussa is 620 miles; or by rail via Buguni will be about 660 miles. The rail journey from Bamako to McCarthy's Island will be 630 miles, and, had the short cut to Talary been adopted, might have been 590 miles.

LIBERIA.-In Liberia it is reported that a concession has been granted to a German firm to build a railway from Monrovia to the frontier of French Guinea.

\section{GERMAN RAILWAYS.}

Togoland.-Turning to the German colonies, the following lines exist in Togoland: A coast line 28 miles long from Lome to Anecho, completed in 1905; a line from Lome to Agome-Palime 77 miles long, opened in 1907, and a line from Lome to Atakpame, 102 miles long, opened in 1911. A local line northwards from Anecho, or eastwards from Tsewie, is projected to develop the rich oil district north of Anecho. The Agome-Palime line will possibly be extended in the future towards Kpandu. It is proposed, when funds permit, to extend the Atakpame line to the interior to serve Sokode and Bassari, and eventually towards Sansanne Mangu to Tchipowa. Unfortunately Togo possesses no good port, the facilities at Lome consisting of an iron pier, as at Kotonu. This pier was badly damaged by the sea in IgI I, but is now repaired.

Caneroons.- In the Cameroons the issues are larger, and concern us perhaps more directly. Two railways are being built. The northern line, roo miles long, from Duala to Ngonsamba, on the lower slopes of the Manenguba mountains, was opened in I9II. The centre line from Duala through Edea is being constructed to Mbalmajo on the river Njong near IVidimenge, a distance of 178 miles. Duala is a port comparable with Calabar, and capable of considerable improvement at a slight cost. 
There is also a narrow gauge private tramway from Victoria to Soppo, 27 miles long, serving the headquarters of the administration at Buea.

A special mission is now investigating the country with a view to deciding on the best direction for the extension of the northern line. The alternatives appear to be the route approximately shown on the map, and a line more to the east via Joko, Tibati, and Ngaundere. It is proposed to carry this line eventually to Garua, and even to Kusseri, as the Germans seem convinced that the Benue River will not suffice as the outlet for their northern provinces. Captain Mercier, in an article published in November, 19I I, in L'Afrique Française, arrived at an opposite conclusion, and recommended connecting the Benue and the Logone rivers by a railway to serve the French Chad and Shari territory. It is perhaps worth going into the matter for ourselves.

The Benue is navigable up to Yola for vessels of 200 tons cargo capacity for three months in the year, and during this period the conveyance of traffic to Garua can be guaranteed by lessening the amount of cargo or using slightly smaller vessels from Yola onwards. Assuming that the Benue fleet is based on Lokoja, to which point boats containing $I, 000$ tons of cargo have access during the Benue flood season, each vessel can only be counted on to make four return journeys to Yola in the season. Now the whole of the Government fleet, excluding the smaller vessels, has a cargo capacity of about 1,800 tons, representing some 600 tons weight of paying cargo, so that in the three months the Government fleet could at most, if fully employed, bring down 2,400 tons of produce a year, or if the faster vessels made five trips, say, 2,700 tons weight. I doubt if the whole of the existing fleets on the Niger could bring down 7,000 tons a year from Yola and beyond; but nothing like this amount of shipping will be available, as it is obviously out of the question to have special vessels for the Benue traffic only-laying them up for most of the year-and it will only be possible to withdraw vessels from the Niger service in the case of river carriers who command sufficient business to justify chartering vessels carrying 1,000 tons, known as " branch boats," for the Niger, during high-water, thus releasing the sternwheelers for the Benue. Under the circumstances, apart from the disadvantage of the short period the river is open every year, the Benue could not cope with the tonnage which may reasonably be expected in the future from the French and German sources, in addition to that originating in Northern Nigeria. Moreover, the distance by river from Garua to Forcados is about 870 miles, and a rate of \&6 per ton was charged to the French for this distance. A railway from Garua to Duala might possibly not exceed 500 miles, so that an average rate of $3 \mathrm{~d}$. per ton mile would successfully compete with the river. Under the circumstances any road or railway between the Logone and Benue would feed a line 
to Duala in preference to the River Benue. The railway would also develop the country passed through, and greatly facilitate the administration of the Cameroons. Therefore it will be built and will tap Yola and Eastern Bornu in the absence of a competing line.

The centre line from Duala to Mbalmajo was chosen to develop the central part of the Cameroons in preference to a line from Kribi to Ebolowa, advocated by the merchants at Kribi. The principal objection to Kribi appears to be that it will never be a good port. From Mbalmajo the $\mathrm{Njong}$ is navigable all the year to Abong Mbang, only 30 miles from the Dume River, which at high water is navigable downwards for 125 miles to within about 100 miles of Nola on the navigable Sanga. An extension of the centre line via Gamane and Kunde to the navigable Logone, or a branch from the northern line to the Logone, especially if the eastern route is chosen, might capture the trade of French Shari territory more effectively than could be done by a line from the Logone to Garua.

An alternative scheme to the Kribi-Ebolowa line is a railway from Kampo eastwards to compete with the suggested French line from Libreville to Wesso.

\section{SIERRA LEONE AND THE GOID COAST.}

Sierra Leone.-Turning now to the British colonies, we have in Sierra Leone a splendid harbour at Freetown, which will probably some day be provided with wharves for berthing ocean steamers, and a trunk line of $2 \mathrm{ft} .6$ in. gauge from Freetown to Pendembu, 228 miles. There is a branch line from Boia junction to Roruks, which is being extended across the Rokelle River towards Makene, a total distance of about 90 miles, about half of which has been completed. Looking at the map, the main line would appear to tap a portion of French Guinea lying east of Sierra Leone and north of Liberia, but a heavy duty is placed on imports into French Guinea through a foreign country, with a view to the imports, and consequently the exports, being diverted via Konakri. This is only possible in the case of valuable commodities like rubber, which can stand the rate via the longer route. Low grade produce from the hinterland may have to go by the cheapest route or not at all. On the other hand the Konakri railway will continue to divert the trade of the northern provinces until the extension of the northern branch of the Sierra Leone Railway renders effective competition possible.

There is a mountain line six miles long connecting Freetown with the Hill Station, some goo feet above sea level.

Feeder roads are being constructed to open up the country traversed by the railway. The Sherbro district is well served by several rivers, and the harbour at Bonthe is available for vessels of a draught of 18 feet. 
Gold Coast.- In the Gold Coast a $3 \mathrm{ft}$. 6 in. gauge line, 170 miles long, from Sekondi to Coomassi, has been in operation since 1903, and a branch line 20 miles long, from Tarquah to Prestea and Broomassie, was opened in IgII. Sekondi is the best port on the Gold Coast at the present time, being accessible by tugs and lighters instead of surf boats only, as elsewhere, but ocean boats have to discharge and take on cargo in the open roads. This port is now being improved. If it is possible to secure a better harbour with smooth water for ocean boats it would not only be better, but cheaper in the long run, for the colony to make great sacrifices to acquire such a port. A decision on this point must precede the framing of any comprehensive scheme of railways.

Attempts have been made to improve the landing facilities at Accra, but with qualified success, and a railway has been built for about 40 miles from Accra to Mangoase, and though only opened in I9I I, is already paying well with cocoa traffic. The problem now is in which direction to extend this latter line, whether to Coomassi, in which case competition with the Sekondi line will at once be introduced, or more or less parallel to the coast to the Sekondi line, in which case most of the traffic will go to Sekondi, or northwards to open up new country. It appears that extensions of either line northwards beyond a certain point will have to traverse a sparsely populated belt, but in the long run a trunk line to the north will probably have to be constructed in view of French and German competitive lines, and if so it will be better to go through first and secure the traffic. The policy up to the present has been to construct trunk roads north of Coomassi, but there is all the difference in the world between trunk lines of roads and a trunk line of railway with feeder lines of roads.

The question of utilizing the Volta River is being investigated, but at the best this could only be regarded as a temporary main line of communication.

\section{NIGERIA.}

Existing RaILIVAys.-There remains to be considered Nigeria, our most important possession on the IVest Coast. TVe find at present a $3 \mathrm{ft}$. 6 in. line from Lagos, through the large centres of Abcokuta, Ibadan, Oshogbo, and Ilorin to Jebba (307 miles), across the Niger, partly by a bridge and partly by temporary train ferry, and via Zungeru-the administrative capital of Northern Nigeria-to Minna, where it joins a line from Baro, on the Niger, to Kano, the famous market of the Hausa States. The distance from Lagos to Kano is 712 miles, and from Baro to Minna 111 , and Kano 356 miles. A branch 90 miles long has been constructed from Zaria to the Rahamma River towards the principal tinfields, and it is decided to extend this line to the top of the Bauchi plateau in the direction of Bukeru, both to serve the tinfields and to give 
access to the healthier uplands. Unfortunately this branch line has been built in a $2 \mathrm{ft}$. 6 in. gauge, thus saddling the country with what will be an ever-increasing disadvantadge unless a decision is faced to alter this line to the standard gauge of Nigeria and banish the $2 \mathrm{ft}$. 6 in. material out of the country. The French have had one or two narrow escapes in the past of introducing mixed gauges, but have luckily come through without, I believe, a single instance in IVest Africa.

In Nigeria we have ample scope for building "railways in the air." Great controversies have taken place in the choice of ports, Warri having been suggested as an alternative to Lagos as the port of the Western line. It has, however, been decided to plump for Lagos, and heavy works are being undertaken with a view to making the bar possible for ocean steamers, which at present transfer passengers to surf boats, and thence to "branch boats" in the open roadstead, and discharge their cargo at Forcados into branch boats for return to Lagos. Forcados, the ocean port for the Niger traffic, is a good harbour, accessible over a $19 \mathrm{ft}$. bar. From this port two independent lines of sternwheelers serve the Niger and Benue. Baro, the starting point of the Northern Nigerian Railway, has always been accessible during two-and-a-half months by steamers drawing I I feet and conveying I, 000 tons of cargo; for nineand-a-half months by sternwheelers drawing four feet and conveying 200 tons of cargo; and all the year round by launches drawing two feet. It will be seen that even without artificial improvements to navigation, the Niger will be a formidable competitor of the Lagos Railway.

Extensions in Southern Nigeria.-The dense population of Southern Nigeria will no doubt justify the construction of local lines not forming part of the main arteries of communication with the interior. To the east of the Niger a line some 60 miles long has been surveyed to connect Onitsha with the Udi coalfields, which are believed to be of considerable value. This line, if built, must obviously also connect with other future lines east of the Niger. A future line might run from Warri via Benin, with cross connections between the western line and Onitsha, Lokoja, or Baro. Nor is it likely that the densest population of all round Ikot Ekpene will be left undeveloped; and whether this area will be best served by a line from a secondary coast port such as Bonny or Opobo, or by a line from the head of the permanent Cross River navigation at Itu, will be an interesting point.

The coastal regions will be served by improving the navigation of the network of lagoons.

EASTERn Trunk Line--It appears to have been generally accepted that a second trunk line serving the eastern portion of Nigeria should start from Calabar, and to have been assumed that this line would also serve Kano. A branch of the eastern trunk line directed on Kano would be the shortest route to the 
coast, but would encounter an almost impracticable escarpment running east and west, north of the Benue. It would, however, serve the tinfields, and if in the future such a line is required, a rack section may solve the difficulty as in the case of the Delagoa Bay line to the Transvaal. The eastern port is two days further by sea, so that the Lagos line will always hold its own for passenger traffic. There are, however, already two competing lines from Kano, and the construction of a third may well be deferred till the Sokoto and Yola-Bornu areas have been provided for. Both these areas are likely to be threatened by foreign competitive railways, a fact which renders it necessary to make our trunk lines as direct as possible and ahead of competing lines.

As regards Bornu, it has already been shown that the Benue and Niger cannot compete with a direct railway from the coast to our eastern frontier, and the first consideration in selecting a trunk line to serve competitive areas such as Maidugari and Yola, is that the cost of transport to the coast should not be greater than by the German line from Garua.

Unfortunately the most direct line from Calabar, the inevitable port of Eastern Nigeria, would start by traversing a sparsely populated region, and the Shebshi mountains south-west of Yola might necessitate a detour or lead to Yola being served by a branch line. In the face of more attractive projects in other directions, and in the absence of reliable information regarding the country, there appears to be no immediate prospect of such a trunk line being constructed, but it is hoped that meanwhile local schemes will not be entered on which might clash with the requirements of the future.

Cross Country Line in Northern Nigeria.-A cross country line useful for administrative purposes might be made from the Bauchi branch line some 40 miles from Zaria eastwards between the Ninghi Hills and the northern spurs of the Bauchi Highlands, via Nafada, the head of the navigable Gongola (a tributary of the Benue), to join the eastern trunk line, and it would probably pay to construct this line to develop Bornu until such time as the value of the traffic and the prospects of competition justify the eastern trunk line being undertaken.

Western Trunk Line.-Turning to the west of Nigeria; Jebba, the point where the Lagos railway crosses the Niger, is the head of the navigable Lower Niger, being accessible by vessels drawing five feet during six months of the year, though for two months the draught available is under two feet. Above Jebba for about 120 miles up to Sekachi, navigation is impeded by a series of rapids quite impracticable for steam vessels and only passable by large canoes with difficulty during the high water. There is no possibility of improving this section of the river. Above Sekachi the Niger is again navigable up to Gaya in French territory, and to lesser extent up to Kompa, 
where another series of rapids commences and extends with intervals up to Ansongo, whence the river is again navigable for sternwheelers for about 900 miles to Koulikoro.

The Sokoto River or Gulbin Kebbi joins the Niger opposite Gomba, and small canoes can reach the important market of Jega, on one of its branches, all the year round. This river is, however, unsuitable for a main artery of trade, and is used chiefly for local traffic.

The navigable section of the Niger from Sekachi to Gaya intersects every trade route from Sokoto to the coast, and the first railway to reach this section and start a service of river steamers will have the best chance of securing the Sokoto trade.

As stated before, it is proposed to extend the French Dahomey railway, which at present terminates at Savé, to Paraku and on to Jugu, and with sufficient inducement the line could reach Gaya, the proposed terminus on the Niger, 300 miles from Savé, in rg16.

The population of Sokoto Province is estimated as $1,300,000$, and is densest in the regions bounding the Sokoto River and its tributaries.

Another factor in this particular problem is the possible advisability of building a line from, say, the bend of the Lagos Railway, north of Abeokuta to about Ilesha, to prevent trade being diverted to the French Railway. A possible solution of the Sokoto problem would then be to extend this line through Borgu, across the Niger east of Gomba, and so continue to Jega and Sokoto. This would be the shortest route to the coast, but would traverse a practically uninhabitated region in central Borgu, whose sparse population is found either along the frontier in the vicinity of the trade route from Sokoto, or along the banks of the Niger. It would involve an expensive bridge over the Niger in the middle of a navigable section, and several miles of bank over swamps north of the Niger.

As regards possible future trade from Borgu, this would probably be retained by a line to Okuta only.

Another solution would be to build a line from Jebba east of the Niger to Sekachi, and thence to Jega and Sokoto. This route to the coast would be longer, but sufficiently short to compete with any likely alternative route. The combined length of line, Abeokuta to Ilesha, and Jebba to Sokoto, would be about the same as Abeokuta to Sokoto via Ilesha. The line from Jebba would serve a larger population en route, and be more convenient for administrative purposes. The deciding factor in favour of the Jebba route may be that the Ilesha line is not so important as other lines in Southern Nigeria, while the Sokoto extension cannot afford to wait.

Possible Extension to Zinder.-The Kano Railway may be extended some day to Zinder, the headquarters of the French Territoire Militaire du Niger. The extension would tap a good grain and groundnut district and existing potash traffic, and 
while primarily justifiable only as a convenience to the French would doubtless pay its way in a few years time.

\section{STATISTICS ILLUSTRATING THE RESULTS OF WORKING OF WEST AFRICAN RAILWAYS.}

The development of traffic due to the construction of railways in West Africa has invariably exceeded all expectations, and it would be rash to assert that any section, however unpromising, would not pay its way. In Appendix 2, I have collected some figures of interest concerning West African railways. It will be seen that in I9I I the Sierra Leone Railway earned over $3 \frac{1}{2}$ per cent., the Lagos Railway nearly $4 \frac{1}{2}$ per cent., and the Gold Coast Railway 9 per cent. on their respective capital costs. The newly-constructed Baro-Kano Railway will pay its way this year. The first section of the Cameroons Railway started paying its way as soon as it was handed over to open lines. In 1909 the Dakar-St. Louis Railway cleared II.3 per cent., the Kayes-Niger 2.2 per cent., and the Konalrri Railway 3.7 per cent. on the capital cost, and the Ivory Coast and Dahomey Railways, though not yet paying expenses, were showing very rapid improvements in their returns.

\section{FUTURE CONNECTIONS BETWEEN INTERNATIONAL SYST EMS.}

One is led to speculate on the chances of intercommunication at some future date between the British, French, and German systems of transport in VVest Africa. It may be premised that international systems will not be linked up except for their mutual advantage. The most likely circumstances to fulfil this condition appear to be the desire for the cheapest outlet to the coast, the desire to use the railway of an intervening country for intercommunication between two colonies of the same European power, and the advantage of obtaining cheaper coal from West African sources.

The first of the above reasons might ultimately lead to a line from the Thiès-Kayes to the Gambia, in view of the necessity for the cheapest possible outlet for the comparatively low grade produce of Upper Senegal and Niger. The district of Kissidugu in French Guinea is more likely to be served by a branch railway from the Konakri line from about Suarella, through Farana, than by an extension of the Sierra Leone Railway.

Assuming that a railway is built from the Lagos line in the direction of llesha, a likely connection would appear to be between this line and Paraku to facilitate communication between the remainder of French WVest Africa and Zinder, via Kano, and also it may be, to supply the French railways with coal from Udi, a possibility worth bearing in mind when designing the cross lines in Nigeria. 


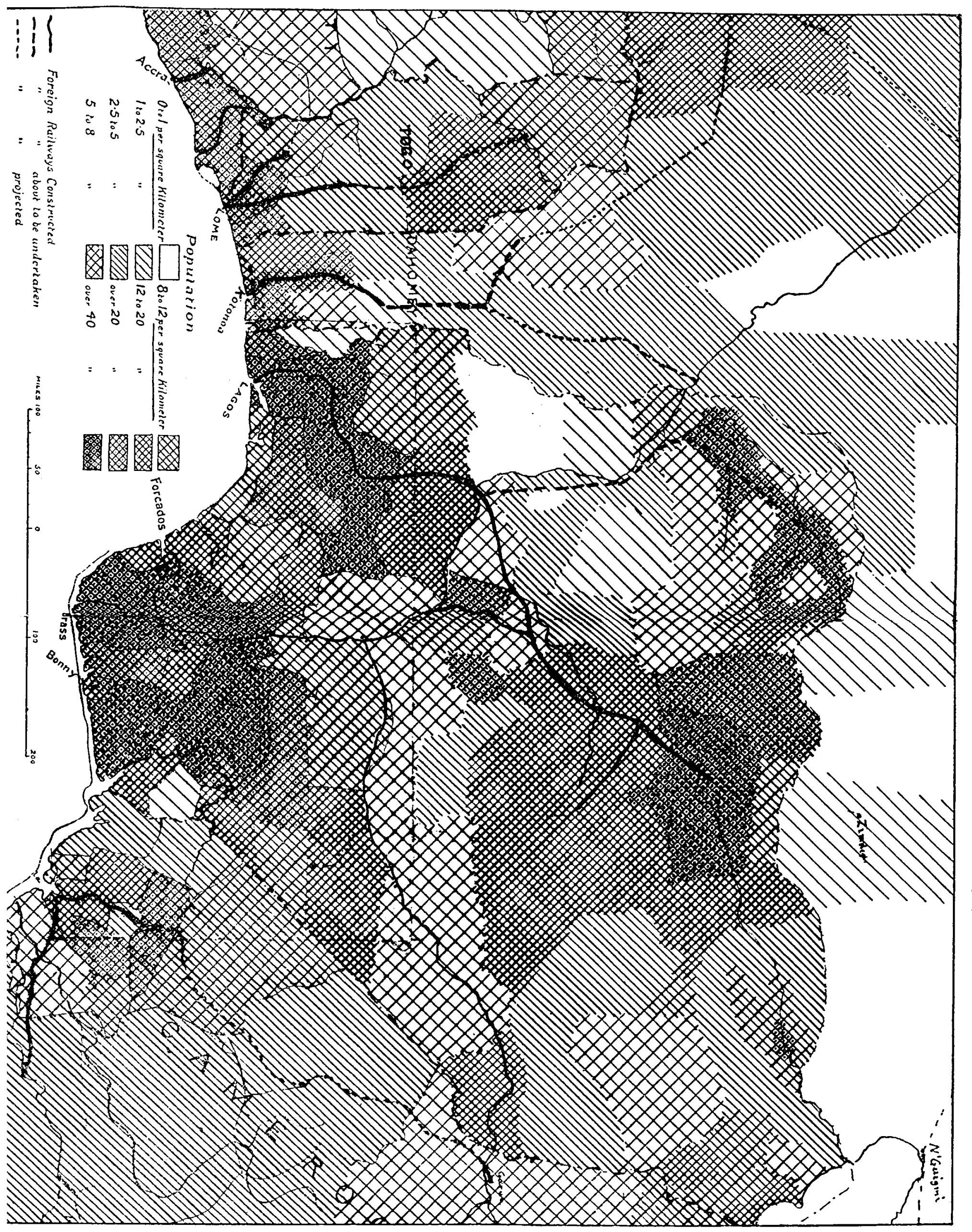


A junction with the German railways appears to be less likely, as it is hoped that coal and oil deposits exist locally in the Cameroons.

SUgGeSted TRANS-AFRICAN RaILWAY.-I am afraid there is no time to review the project for building a railway from Algeria via Lake Chad, to connect with the Congo and South African systems. The proposed branch of this line to connect with the French West African system possesses added importance, in view of the recently-adopted policy of raising a native army in French West Africa for service in North Africa. The length of line to be built would be about 1,700 miles from the Algerian Railway to the Chad, and a 600-mile branch to the French West African system. From Lake Chad to Stanleyville would be roughly 1,500 miles more. The total cost is estimated at about i 3 million sterling for the line to the Chad and branch to the Niger, and about eight-and-a-half millions for the second portion. A reconnaissance party has recently traversed the whole of the proposed route to the Chad and to the Niger, and is understood to have reported on the physical practicability of the scheme, which, if ever carried out, would attract the railways of all West African colonies to itself. At present the prospect of financing such a line may be very remote, but, apart from a possible discovery of minerals on the proposed route, the world-wide demand for accelerated communication, and the rapidly increasing importance of West and Equatorial Africa, may not inconceivably lead to the project maturing in the next generation.

Standard Gauges of West Africa.-Every junction of a British with a foreign line will involve a break of gauge. It is too much to expect the metre gauge to have been adopted from the commencement in British West African colonies on the chance of future connections with foreign systems, although Sir Walter Egerton, in or about Ig04, actually suggested that the 124 miles of Lagos Railway then constructed should be relaid in metre gauge.

\section{CONCLUSION.}

It is, I hope, established that for the development of West African colonies by railways, a comprehensive scheme, based on the application of general principles to local conditions, is necessary from the very first, and it is submitted that no deducible conditions of the future are so remote as not to be given some weight in the framing of this general scheme. As the prosperity of a country increases, its arteries of communication become more and more important, and with increasing competition, disadvantages in the channels of transport, comparatively unimportant in the early stages, begin to accentuate themselves and may possibly have far-reaching influences, while the immediate considerations which governed the transport policy in the first case may have lost their force.

It is realized that conditions change and fresh information is aiways coming to hand to alter the data on which the earlier 
schemes are based, that progress cannot wait indefinitely for facts depending on itself, that lines have been and will be constructed more or less in the dark, that every such line adds to the difficulties of framing the best general scheme, and that a patchwork system may result.

Under the circumstances I venture to assert that the first need is for the systematic collection and co-ordination of data with a view to determining with confidence the future trunk lines of railway. A great deal of information exists in a diffused form, and merely requires focussing to throw valuable light on the subject. Further information will have to be searched for with special reference to railway development, and the man on the spot with full knowledge of local conditions must be trusted to marshal the data and formulate the conclusions. It is not unlikely that the alternatives to choose from may be few. It may be that the route once selected must be closely adhered to, or, on the other hand, that the decision as to alternative routes may be safely reserved, but until the trunk line policy is defined there will always be risk of inconsistency with its attendant evils. Once the question of trunk lines has been settled, every projected and existing line resolves itself into either part of the main line, or a local or feeder line, and further construction can be confidently carried out in the order most profitable.

APPENDIX 1.

RAILIVAY EXTENSIONS AND HARBOUR IMPROVEMENTS PROPOSED FOR EXECUTION UNDER LOAN OF $€ 6,000,000$ RAISED BY FRENCH IVEST AFRICA.

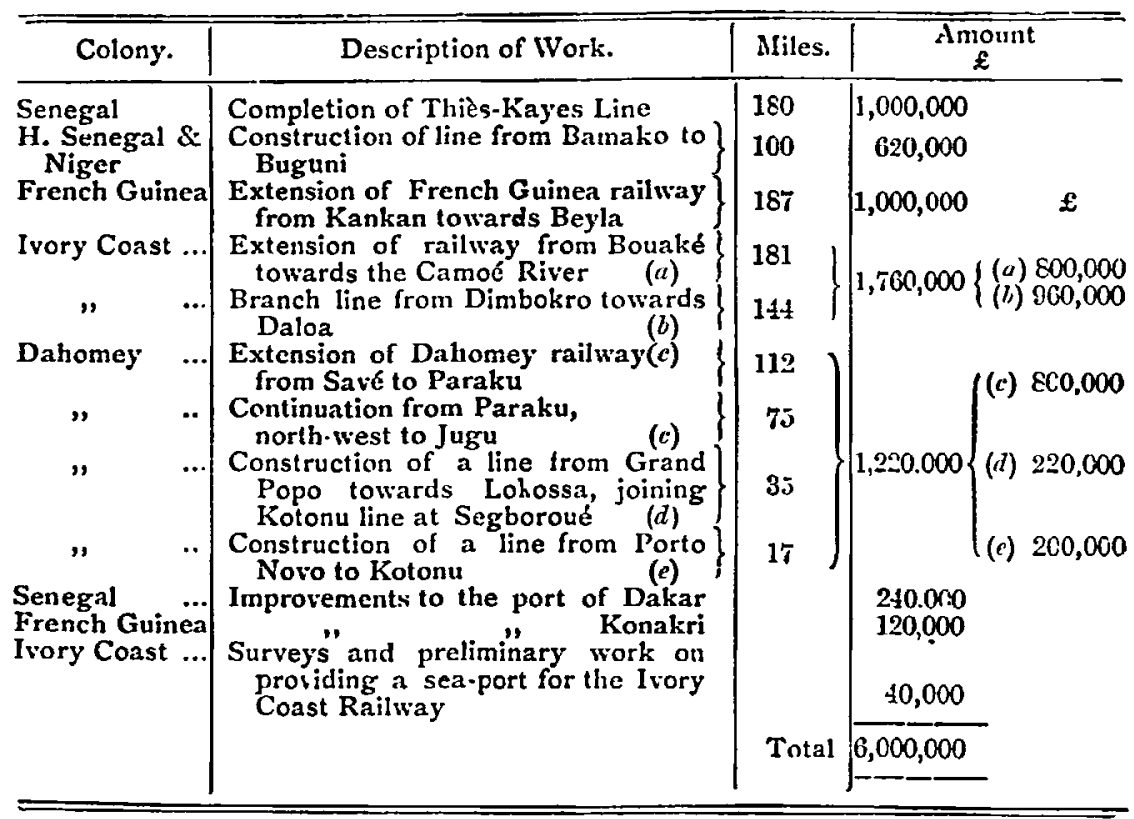


APPENDIX 2.

APPROXIMATE DATES AND COST OF CONSTRUCTION AND RESULTS OF WORKING OF IVEST AFRICAN RAILIVAYS.

\begin{tabular}{|c|c|c|c|c|c|c|c|c|c|c|c|}
\hline \multirow{2}{*}{ RAILTAT. } & \multicolumn{4}{|c|}{ MATM LINE. } & \multirow{2}{*}{ 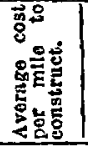 } & \multirow{2}{*}{ Year. } & \multirow{2}{*}{ |riles } & \multirow{2}{*}{ 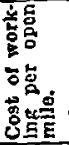 } & \multirow{2}{*}{ 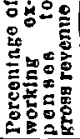 } & \multirow{2}{*}{ 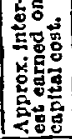 } & \multirow{2}{*}{ 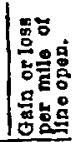 } \\
\hline & $\begin{array}{c}\text { Com- } \\
\text { menced }\end{array}$ & $\begin{array}{c}\text { Com: } \\
\text { pleted. }\end{array}$ & Miles. & Terminus. & & & & & & & \\
\hline Lagos Railway ... & 1806 & 1912 & 460 & Mlinna ${ }^{1}$ & $\begin{array}{l}9,158 \\
9,479 \\
9,670\end{array}$ & $\begin{array}{l}1902 \\
1903 \\
1904-5 \\
1905 \\
1906 \\
1907 \\
1908 \\
1909 \\
1910 \\
1911\end{array}$ & \begin{tabular}{|l|}
124 \\
124 \\
124 \\
124 \\
131 \\
178 \\
214 \\
272 \\
307 \\
307
\end{tabular} & $\begin{array}{c}t \\
309 \\
365 \\
425 \\
452 \\
460 \\
417 \\
482 \\
485 \\
514 \\
576\end{array}$ & $\begin{array}{l}89 \cdot 6 \\
89 \cdot 4 \\
88 \cdot 5 \\
78 \cdot 2 \\
71 \cdot 2 \\
53 \cdot 3 \\
70 \cdot 7 \\
64 \cdot 76 \\
62 \cdot 25 \\
57 \cdot 6\end{array}$ & $\begin{array}{l}2 \cdot 88 \\
3 \cdot 29 \\
4 \cdot 38\end{array}$ & $\begin{array}{r}\bar{f} \\
+36 \\
+43 \\
+55 \\
+126 \\
+186 \\
+366 \\
+200 \\
+264 \\
+312 \\
+424\end{array}$ \\
\hline $\begin{array}{l}\text { Baro-Kano Railw'y } \\
\text { Bauchi Light do. }\end{array}$ & 1907 & $\begin{array}{l}1911 \\
1012\end{array}$ & $\begin{array}{r}356 \\
90\end{array}$ & $\underset{\text { Rahamma R. }}{\text { Kano }}$ & $\begin{array}{l}3,570 \\
2,220\end{array} \mid$ & 1911 & 356 & & & & \\
\hline $\begin{array}{ccc}\text { Gold Coast } & \text { Rail } \\
\text { way } & \ldots & \ldots\end{array}$ & 1898 & 1903 & 170 & Coomass & 10,900 & $\begin{array}{l}1903^{2} \\
1904 \\
1908 \\
1911\end{array}$ & \begin{tabular}{l|}
124 \\
168 \\
168 \\
188
\end{tabular} & $\begin{array}{l}382 \\
582 \\
447 \\
543\end{array}$ & $\begin{array}{l}71 \cdot 59 \\
61 \cdot 76 \\
40 \cdot 61 \\
35 \cdot 71\end{array}$ & $\begin{array}{l}3 \cdot 1 \\
4 \cdot 15 \\
9 \cdot 0\end{array}$ & $\begin{array}{r}+150 \\
+360 \\
+454 \\
+977\end{array}$ \\
\hline $\begin{array}{ccc}\text { Gold Coast-Accra } \\
\text { Railway } & \ldots & \ldots\end{array}$ & 1909 & 1911 & & Mangoase & & & & & & & \\
\hline 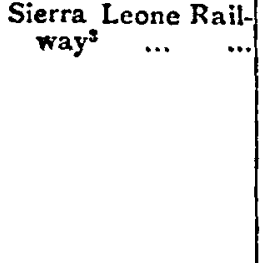 & 1896 & $\begin{array}{l}1904 \\
1908\end{array}$ & $\begin{array}{l}221 \\
228\end{array}$ & $\begin{array}{l}\text { Baiama } \\
\text { Pendembu }\end{array}$ & $\begin{array}{l}4,030 \\
4,122\end{array}$ & $\begin{array}{l}1900 \\
1901 \\
1902 \\
1903 \\
1907 \\
1909 \\
1910 \\
1911\end{array}$ & $\begin{array}{r}55 \\
76 \\
76 \\
136 \\
226 \\
254 \\
254 \\
254\end{array}$ & $\begin{array}{l}260 \\
214 \\
280 \\
235 \\
293 \\
270 \\
262 \\
262\end{array}$ & $\begin{array}{l}138 \\
104 \\
99 \cdot 7 \\
87 \cdot 3 \\
91 \cdot 7 \\
81 \cdot 4 \\
65 \cdot 71 \\
64 \cdot 87\end{array}$ & $\begin{array}{c}\cdot 6 \\
1 \cdot 5 \\
3 \cdot 5 \\
3 \cdot 61\end{array}$ & $\begin{array}{r}-72 \\
-10 \\
+\quad 1 \\
+\quad 31 \\
+\quad 29 \\
+69 \\
+144 \\
+149\end{array}$ \\
\hline Dahar-St. Louis' ... & 1882 & 1885 & 165 & St. Louis & 4,950 & $\begin{array}{l}1886 \\
1887 \\
1897 \\
1898 \\
1909\end{array}$ & $\begin{array}{l}165 \\
165 \\
165 \\
165 \\
165\end{array}$ & $\begin{array}{l}775 \\
570 \\
340 \\
300 \\
490\end{array}$ & $\begin{array}{r}452 \\
286 \\
107 \\
84 \\
46\end{array}$ & $\left|\begin{array}{c}1 \cdot 4 \\
11 \cdot 3\end{array}\right|$ & $\begin{array}{r}-600 \\
-378 \\
-\quad 23 \\
+\quad 67 \\
+560\end{array}$ \\
\hline Kayes-Niger & 1881 & $1906^{5}$ & $3 \pm 7$ & Koulikoro & 5,500 & $\begin{array}{l}1897 \\
1903 \\
1909 \\
1910\end{array}$ & $\begin{array}{l}100 \\
212 \\
347 \\
347\end{array}$ & $\begin{array}{l}173 \\
190 \\
155\end{array}$ & $\begin{array}{r}167 \\
95 \\
56\end{array}$ & $\begin{array}{r}\cdot 2 \\
2 \cdot 2\end{array}$ & $\begin{array}{r}-70 \\
+\quad 10 \\
+120 \\
+114\end{array}$ \\
\hline Thiès-Kayes ${ }^{6}$ & 1907 & 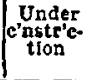 & Wut be & Kayes & & & & & & & \\
\hline
\end{tabular}

1 Minna to Zungeru, 38 miles, built 1910 from Minna.

${ }^{2}$ June to December only.

$326^{\prime \prime}$ gauge. 44 lb. rail.

5 Rails reached mile 347 in December 1904 . Almost entirely native subordinate staff, including engine drivers.

- About 210 miles completed. Work being carried out both ends. Net revenue hayesAmbidédi, 1910, $\$ 18$ mile 
APPENDIX 2,-contd.

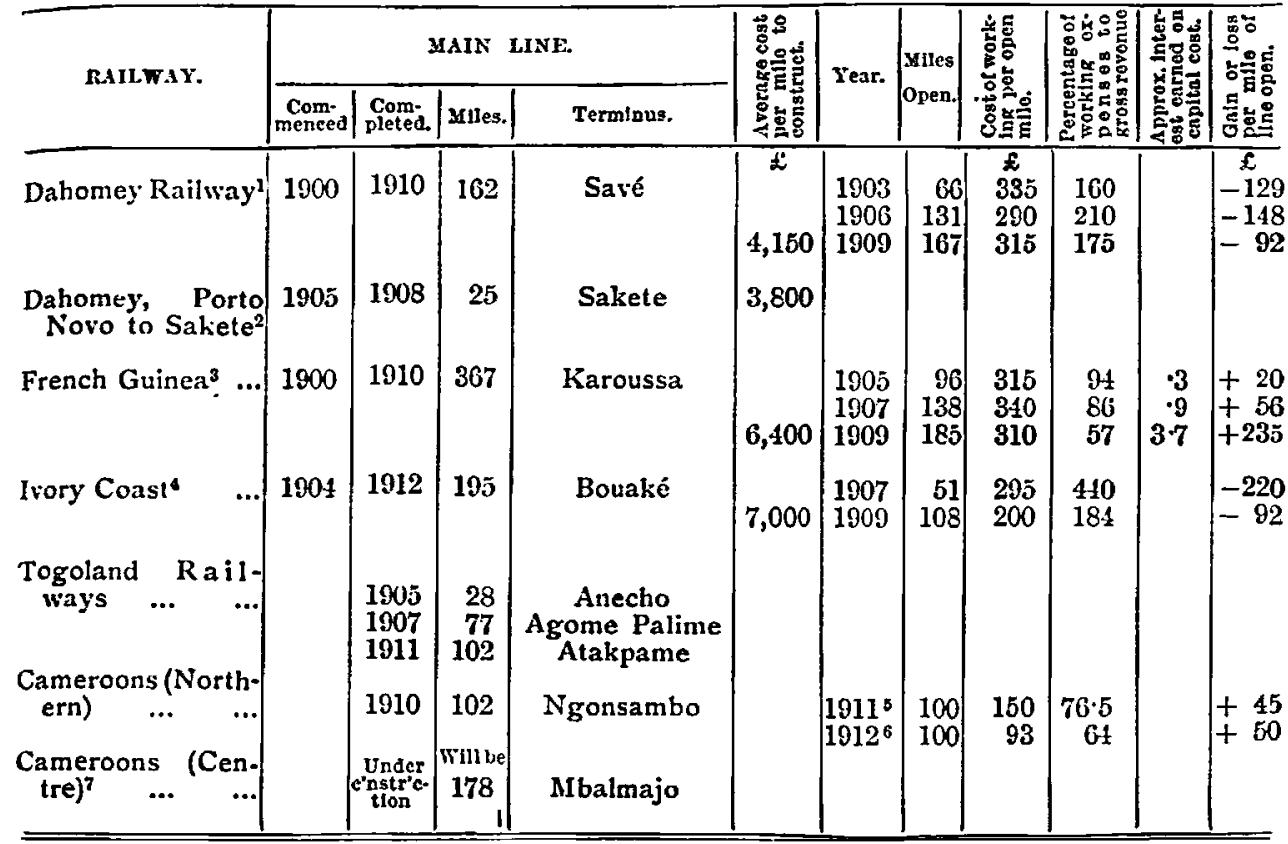

$148 \mathrm{Ib}$. rail. There is a 20 mile branch to Segboroue.

2 Surface tramway over easy country. Gross revenue, $1907 £ 1,556,1909 £ 5,303$.

3 Now being extended 40 miles to Kankan.

- Expenses of working construction traffic have been charged, but no revenue claimed.

s Last nine months only. Entirely native subordinate staff except engine drivers.

- First six months only. $\}$ Three trains a week each way.

7 Line reached Edea, 1912.

NotE.-In 1911 the working of the Thiès-Kayes ('Thiès section), Kayes-Ambidedi, KayesNiger, Konakri-Karoussa, and Ivory Coast lines resulted in a net revenue of \&119,010.

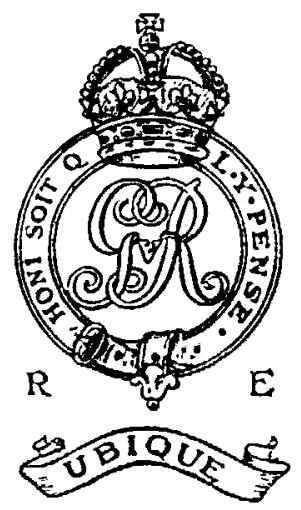




\section{DISCUSSION.}

The Chairman, Sir Clement HIII, K.C.B., K.C.M.G., M.P.: In order to start the discussion, as there seems to be some reluctance amongst well. informed members of the society to send up their names or cards, I will take the liberty of committing a breach of the rules, by calling upon Mr. Frederic Shelford, who we know has had so much to do with the construction of the railways in West Africa, and whose lecture at the Institution of Civil Enginecrs I had the pleasure of listening to a short time ago. I will ask him to favour us with a few observations on the paper.

Mr. Frederic Shelford: I thank you very much for the honour which you have conferred upon me, Sir Clement, in asking me to make a few remarks. And in response to the invitation, there are perhaps a few observations which I might make to add to the interest of the paper which we have heard. First, some general conclusions in regard to the African railways.

\section{Competition between River and Railway.}

Captain Mance said, at one point in his paper, that the Niger River formed an important competitor with the Nigerian Railway to Lagos. That, of course, remains to be seen, but as a general rule, I think we may take this as the fact, that railways cannot compete with ocean-borne traffic. That, I think, is fairly obvious. With regard to the Cape to Cairo Railway, which has been spolsen of, if you were sending goods to the Cape, even if that railway were built, you would hardly expect that it would be cheaper to take them right across Africa than round the Cape by sea. And even with regard to passenger traffic, if a passenger were not in a great hurry I am sure he would find it more comfortable to go by Union Castle steamer than to go across Africa in a jolting train. With regard, however, to the problem of the partially navigable river, that is quite different. The Niger River I have been up at any rate once, with Sir Percy Girouard, and at his request made a rough survey. I found that it is not navigable for any vessel all the year round, at any rate when you get above Lokoja, and even below that it is not very navigable, even for steamers drawing two feet only, because I myself was once stuck on a sand-bar for $3^{6}$ hours. And under those conditions, when you have valuable commodities to carry, I think it is more likely that they will be sent by rail than by the river. Sir Percy Girouard based a scheme of communication in Nigeria upon the Niger River; he pointed out that that river was not being used at all, or hardly at all, and his idea was to convey goods up and down the river as far as Baro, and from there by the Baro-Kano Railway. It remains to be seen whether Sir Percy Girouard's scheme will work out, because in competition with that you have the Nigerian Railway, which, I think, is more likely to get the traffic.

\section{The Question of Railivay Gauges.}

I must say a word about the question of railway gauge in West Africa, which Captain Mance has mentioned. Africa has now, in spite of all the efforts of a great many of us, got into a fearful jumble with regard to gauges: South Africa 3 ft. 6 ins.; Egypt $4 \mathrm{ft}$. $8 \frac{\pi}{2}$ ins. and $3 \mathrm{ft}$. 6 ins.; Uganda the metre gauge; all the French railways of West Africa the metre gauge; Sierra Leone $2 \mathrm{ft}$. 6 ins.; Gold Coast $3 \mathrm{ft}$. 6 ins.; Nigeria $3 \mathrm{ft}$. 6 ins., and $2 \mathrm{ft}$. 6 ins. $A s$ far as the last is concerned, $I$ did all 
that I possibly could about five years ago, practically unassisted, to prevent the introduction of the $2 \mathrm{ft}$. 6 in. gauge into Northern Nigeria, but somehow it has managed to arrive. I think the lesson of India, with regard to gauges, is one which should not be forgotten. The state of things in India now is such-I do not know India personally, but 1 know a good deal of it-that in parts of it you actually have two railways running side by side, one of one gauge and the other of another gauge. The beginning is so insidious, it is like a disease. At one time you want to make a little railway. You have not much money for the purpose; you make out that a $3 \mathrm{ft}$. 6 in. gauge railway would cost so much, and that a $2 \mathrm{ft}$. 6 in. gauge one would cost a little less. You yield to temptation-which is always a bad thing-and you go in for the little gauge, $2 \mathrm{ft} .6$ ins. Then a time comes a little later, when you want to extend. it. That has happened in Northern Nigeria, and this line to the tin fields has to be extended, and you have not the courage to alter the gaugeor I ought to say you may have the courage but I have never seen it shown yet-and so you extend it on the $2 \mathrm{ft}$. 6 in. gauge again. And so on it creeps, until it is possible you will have in Africa, as you find in India, two railways running side by side of different gauges, and the thing getting hopelessly mixed up.

\section{Far-sigited French Railway Policy.}

One of the most instructive parts of the paper is, I think, that which deals with the French railways, and the way in which the French have laid out in advance schemes for future lines. And I think one must be impressed, on looking at the map, much more with what they have done than with what we have done, and by the absence in our case of a comprehensive scheme laid out in advance. There is, as a matter of fact, pigeon-holed in the Colonial Office somewhere a report, which was made by my partners and myself, I forget how many years ago, as to the future extensions of British railways; but probably it has now got covered up with dust and forgotten. I do not know that I can say anything more, except to thank Captain Mance for his paper, which has been most interesting.

Dr. T. Miller Maguire, M.A., LL.D.: I should like to ask a question. Very grave doubts are often expressed as to whether African or American natives have hitherto benefited in the least by the introduction of European civilization-falsely so-called. I know that Khama protested that railways would ruin'Bechuana! Does the gallant Lecturer believe that any material or moral benefit will accrue to the natives by the proposed railways, French and British, which he has so very ably described? Will the male or female natives in the districts traversed by these rapid means of transit not lose more than they will gain? Will they be exploited? Shortly, will any material or moral good to humanity at large arise in these benighted lands from the railways? Is there not a great danger of the natives becoming mere decadent adjuncts of machines, like the poor victims of the "Manchester School" in Lancashire or Lanarkshire. I would much prefer that my friends should be native warriors than North of England miners. The native women-as they are-must be far superior in every way to the poor sweated girls on coal pit banks, or in factories, or in the Liverpool or Glasgow slums, which I have explored. IVill the effects of railways be human degeneracy or improvement? This is a vital matter in my mind, and of strategic importance with regard to the 
future of the military forces of West Africa, and of more importance to all of us here than whether the management of these new, and, perchance, deadly innovations, be in the charge of Stäte bureaucrats or of commercial adventurers.

The Chairman, Sir Clement Hill, K.C.B., K.C.M.G., M.P.: It is my pleasant duty to say a few words on this paper. And though 1 cannot pretend to say anything on the technical part of it, I can say that it has given me immense pleasure to come here to-day, because all the names which have been mentioned now, the railway termini and the places of interest for the future construction of railways, were names most familiar to me in those great proceedings which took place, and which terminated in $1 \delta g \delta$, when we were discussing with France the division of these districts. At that time all the explorers and those engaged on the delimitations had to go on foot, and there was hardly a sign of a railway, if such did exist at that time. It is almost impossible to realize that thuse places were so little in touch then, and yet are so close now. And we are trying to bring them into still closer communication by means of the railway.

\section{Governaent and Private Enterprisk.}

There is a point which our Lecturer did not touch upon, one which struck me first on reading his paper, and that was, that he only deals with the construction of railways by the Governments of the countries. I know it has been a cardinal principle with the Crown Agents, of this country at all events, and, I daresay, with the Government institutions of other countries, that they can build railways cheaper than commercial companies can, and that therefore they begin by building these railways in these wilder countries, so far as they can, for the Government, instead of putting them out to contract. But I have always held, that-though it may be possible, and though it certainly is desirable, that such a scheme as has been foreshadowed by Captain Mance should be borne in mind by the Governments, and that they should keep their eyes on the strategical and commercial advantages that are to be obtained from the carefully thought out construction of railways in this country-it is nevertheless open to question whether, when we have built railways-if they are to be built cheaper by Government contracts and enterprise-they should not be offered to private companies to develop. Of course, that is a very unpopular view with many people, I know, because there is a great tendency now to nationalize the railways and everything else. At the same time, it seems to me it is very difficult in this country which we have been talling about, to get railways developed. This is not a political question; whichever Government is in power has very great difficulty in coming to the House of Commons and saying I want a large grant of five or six millions so as to carry out a comprehensive scheme of railway development in this or that country. We can remember all the opposition there was to the Uganda Railway, which was built by the Government, not as a commercial enterprise, but to carry out our obligations under the Brussels Act, which constrained us to develop countries that we had taken over and to put down the slave trade. Now, in spite of what Mr. Harcourt has done-and I give him great credit for his wish to develop these railways-he would agree that it is very difficult to come to the House of Commons and get these large grants whenever developments and feeders are required for certain railways. And it can only be done by the expression of opinion by those who hold the view that it would be conceivably worth 
while to sell some of these railways, or make them over under certain conditions as to transit rights, etc., with provision that the trade shall not be stifled in any way, so as to see if they could not develop the country quicker than we can by Government enterprise. That has always been more in my mind than anything else when I have heard of these Government railways, or have had, as I did with the Uganda Railway, to take part in their construction. At all exents, I think the idea is worth considering.

\section{The Problem of Native Labour.}

There was nothing in the paper to show us how these railways are built, how we get native labour, what labour there is, how it is employed, whether there is a sufficient supply of it, whether it comes very willingly, or whether any pressure has to be put on the chiefs to cause them to supply it. We know that there are very great risks in the obtaining of native labour in the building of railways: in the construction of the Uganda Railway we could not get any native labour at one time, and we employed 26,000 Indian coolies on the line. Though they enabled us to build the railway, it was a very expensive method of getting labour; we were hampered by all sorts of regulations by the Indian Government, with the object of ensuring that the labourers should be well treated, and at that time we had to press the railway on. But we were unable to get native labour; and I should like to hear, if Captain Mance can tell us, how the supply for the construction of this railway is obtained in West Africa.

The Lecturer, Captain H. O. Mance, D.S.O., R.E., in reply, said: With regard to the navigability of the Niger, time will show to what extent this river can be relied on. If, however, nothing further is done to try to improve the river, the trial cannot be considered a complete one. At present, during low water, the chances of a vessel grounding are as largely dependent on the skill of a native pilot as on the depth of the channel.

\section{Construction by Government or Companies.}

Referring to the Chairman's remarks on the subject of the construction of railways by Government, it is hoped that the success of railway construction in Nigeria will be a very good argument in itself for Government continuing to construct railways. I think the Chairman had principally in mind the very important matter which is half the business of constructing railways, and that is the provision of funds. It is to be feared, however, that if companies are allowed to construct railways, they would be concerned more with making them pay than with the development of the country by them, which is the main object of a Government. As regards the provision of funds, it is not necessary to furnish a very large amount all at once; it would be probably better for the Government to furnish sufficient funds to construct, say, 200 miles of railway a year regularly. That would enable traders to follow up the railway as it is extended, and it would have the added advantage of cheapening construction by retaining the same staff of engineers and foremen on the work. I hope the Chairman's remarks will be taken to heart in the right quarter, and that money will be forthcoming, because I am certain it will be very well spent, and it will repay itself again and again.

vOL. LVII. 


\section{Native Labour.}

I should have preferred that Mr. Goldsmith, who has written able articles on the subject, should have given us his views on the subject of the employment of native labour on the Nigerian Railways. The system employed in Northern Nigeria has been since strongly recommended in a French paper for introduction into French VVest Africa. It depends on enlisting the co-operation of the political staff in the administration of labour. This was most successfully accomplished in Northern Nigeria, where the political and railway staffs worked in complete harmony. The principle was, as far as possible, to keep the same organization on the works as in the villages. The natives who worked together were recruited from the same district; they came with their own headmen, and they lad their own miniature villages alongside the railways. As far as possible, we employed only those who lived near the work. Labourers were well treated by people who thoroughly understood them, as the railway staff very soon got to know the conditions of the country. The adoption of task-work resulted in a full day's work being usually completed at an early hour of the afternoon. Wages were paid into each labourer's own hands in cash by a European paymaster. The result was that the natives knew they could expect actual money for the work they did, and that they could do with it what they liked. We went to considerable trouble-and sometimes it was a great nuisance-to pay these labourers once a week. The question of food supply received constant attention. The only natives who came from the coast were artizans, who could not be obtained locally. A limited quantity of floating labour was also available.

I am unable to give you further information on the subject of coal in Nigeria, but I understand it is considered to have better prospects than the lignite, which is found in the same neighbourhood.

I do not think I can go into the question of whether railway construction tends to improve the condition of the inhabitants. It seems to me that this point is more an ethical one, and is beyond the scope of this lecture. I may, however, be allowed to mention one phase of it. Assuming it is desired to give the natives the best administration we can; this administration costs money, and, in order to get the money without injustice to the inhabitants, it is necessary to increase their prosperity. That cannot be effected beyond a certain point without means of communication, which will enable them to expand their markets. Therefore, from the point of view of the philanthropist, the improved administration which we feel we can give to these natives-better administration, we think, than that of other great nations-can be obtained indirectly by providing railways.

I think I have now dealt with all the points which have been raised.

The Chairman: I have only one more duty, and I am sure you will join with me in conveying a hearty vote of thanks to the Lecturer for his interesting lecture to-day. As far as I am concerned, the remarks which he has made with regard to labour are satisfactory, and he shows that the labour employed in building the railway has been used in quite the right way. 


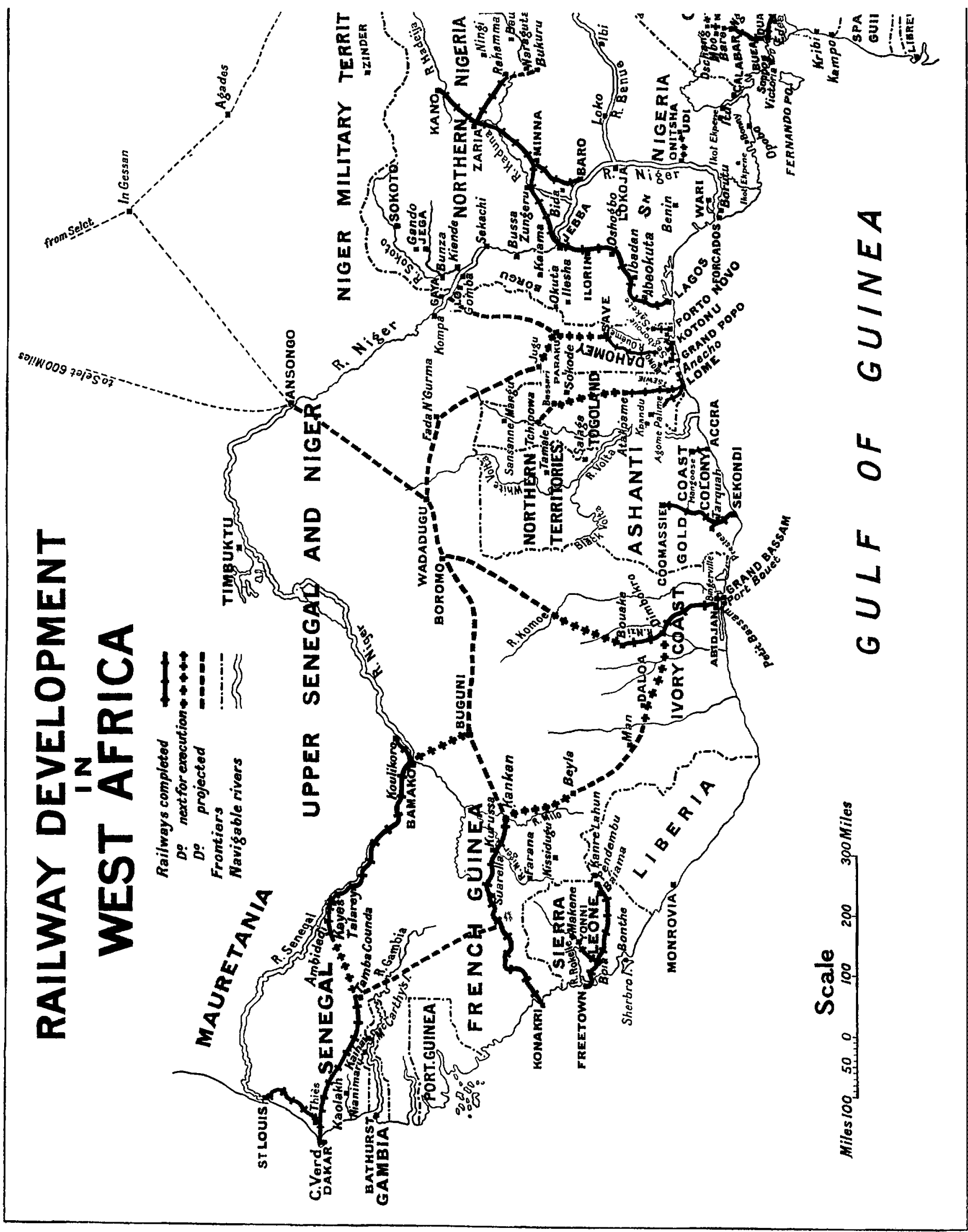




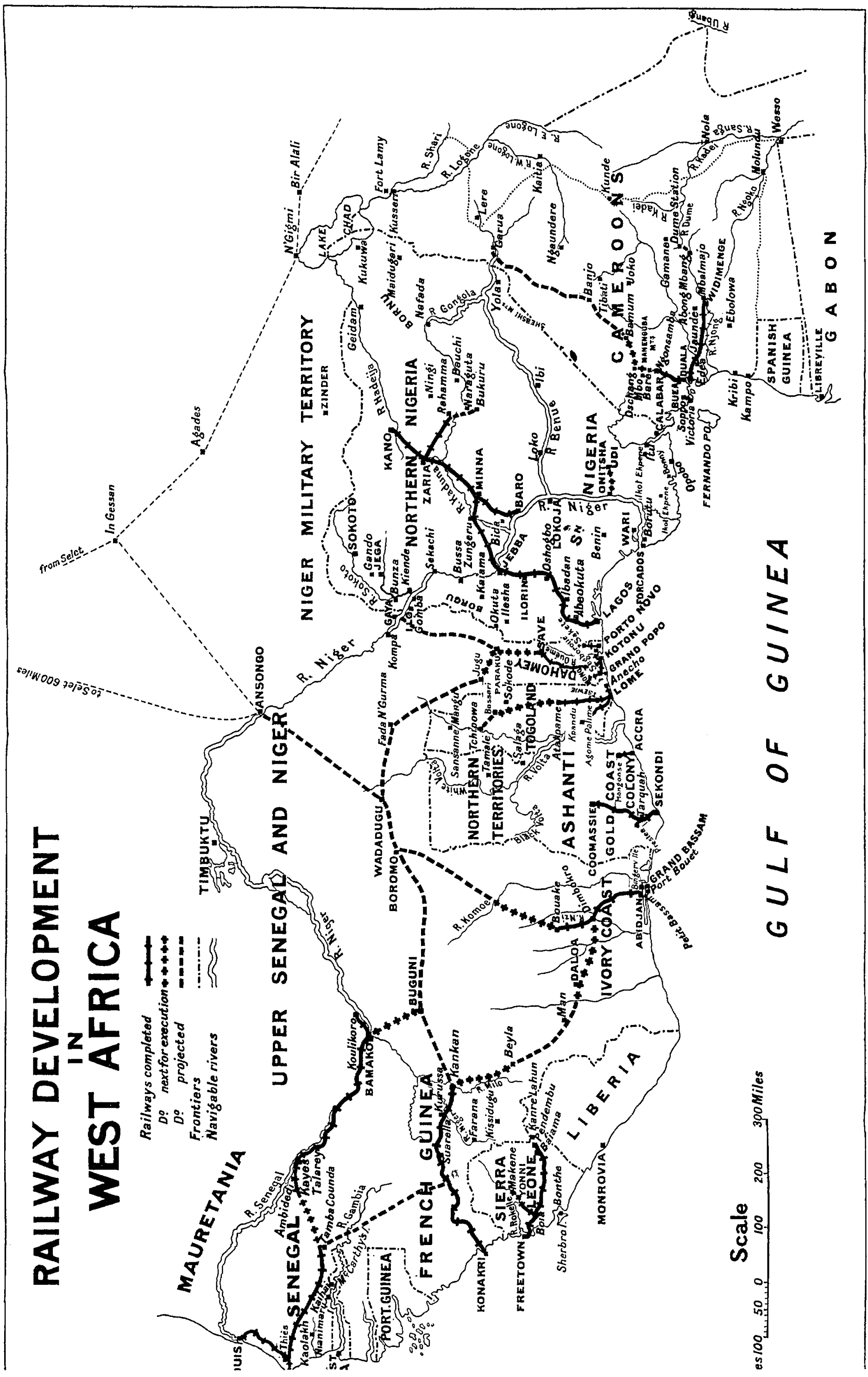

